directors on public problem/policy research. In many instances the research process is not that different from purely theoretical/academic research.

4. Newspaper Political Analyst/Columnist: Although the number of big-city dailies has diminished markedly in the last few decades, there's a concurrent proliferation of suburban and county weeklies and dailies all of whom have column inches to fill. Local analysts are frequently preferred over the nationally syndicated.

\section{Foreign Student Travel Grants}

Please see "Research and Training Support" in this issue of PS for information on foreign student travel grants to the 1989 APSA annual meeting.

\section{APSA Offers Free Child Care at Annual Meeting}

Child care services will be available without charge to Annual Meeting registrants in Atlanta from Thursday, August 31 through Sunday, September 3, at the Atlanta Hilton.

The hours will be 8:30 a.m. to 10 p.m. from Thursday through Saturday. On Sunday the service will be available from 8:30 a.m. to 12:30 p.m. Snacks will be available for the children.

Members wishing further information on the 1989 Child Care Service and registration forms should write:

\section{Child Care Coordinator APSA \\ 1527 New Hampshire Ave., NW Washington, DC 20036}

The service is offered by the Association in response to a request from the APSA's Committee on the Status of Women in the Profession.

\section{Placement Service Set for Meeting}

The first step in the academic job search begins with the Annual Meeting Placement Service which will be available again at the 1989 Annual Meeting.

The Service allows employers to review the vitae of job applicants and to interview them at the Annual Meeting. Also, applicants can review the list of positions which are open in their respective fields and can apply for positions in which they are interested.

The Placement Service will be open from August 3 I to September 3 and will be in the Grand Salon of the Atlanta Hilton Hotel.

To participate in the Service, APSA members are urged to register prior to the opening of the Annual Meeting. Placement registration forms are available in the back of this issue of PS and in the APSA's Personnel Service Newsletter.

\section{Shklar Featured at ACLS Meeting}

Association President-Elect Judith Shklar delivered the Charles Homer Haskins lecture at the annual meeting of the American Council of Learned Societies April 6.

Charles Homer Haskins was the first chairman of the American Council of Learned Societies. In 1983, to recognize Haskins' signal contributions to the world of learning in the United States, the ACLS inaugurated a series of lectures entitled "The Life of Learning" in his honor. Designed to pay tribute to a life of scholarly achievement, the Haskins lecture is delivered by an eminent humanist. The lecturer is asked to reflect and to reminisce upon a lifetime of work as a scholar, on the motives, the chance determinations, the satisfactions and the dissatisfactions of the life of learning.

Previous Haskins lecturers were John Hope Franklin, Carl E. Schorske, Milton V. Anastos, Lawrence Stone, Mary Rosamond Haas, and Maynard Mack. 